As-Syari: Jurnal Bimbingan É Konseling Keluarga

P-ISSN 2656-4807

E-ISSN 2656-8152

\title{
PENGARUH KONDISI EKONOMI KELUARGA DAN MOTIVASI BELAJAR \\ TERHADAP PRESTASI BELAJAR SISWA PADA MATA PELAJARAN \\ KEWIRAUSAHAAN KELAS XII DI SMK TEKNOMEDIKA 2 CIBUNGBULANG BOGOR
}

\author{
Yati Nurhidayati \\ nurhidayati@as-syari.net \\ Program Studi Pendidikan Agama Islam \\ Program Pascasarjana IAI-N Laa Roiba Bogor \\ Nanat Fatah Natsir \\ nanatfnatsir@laaroiba.ac.id \\ Program Pascasarjana UIN Sunan Gunung Djati Bandung \\ Efrita Norman \\ efritanorman@mes-bogoraya.net \\ Program Pascasarjana IAI-N Laa Roiba Bogor
}

\begin{abstract}
This research is motivated by the Family Economic Conditions, Learning Motivation, and Student Learning Achievement. The purpose of this study was to analyze the influence of Family Economic Conditions and Learning Motivation Against Student Learning Achievement in Entrepreneurship Class XII in SMK Teknomedika 2 Cibungbulang Bogor. This research was conducted using a sample of 42 students, using a random sampling technique from a population of 140 students. Consists of independent variable the Family Economic Conditions ( $\left.X_{1}\right)$, Learning Motivation ( $\left.X_{2}\right)$ and dependent variable Student Learning Achievement (Y). Researchers use quantitative data analysis, the stage of implementation of the analysis includes: (1) descriptive analysis, (2) classical assumption test (prerequisite) and (3) hypothesis testing. The results of this study indicate that: 1) There is a significant influence on the family economy of student achievement in SMK Teknomedika 2 Cibungbulang Bogor by 50.7\%. 2) There is a significant influence of learning motivation on student achievement in SMK Teknomedika 2 Cibungbulang Bogor by 51.0\%. 3) There is a significant influence between family economy and learning motivation together on student achievement in SMK Teknomedika 2 Cibungbulang Bogor by 69.7\% while the remaining 30.3\% is influenced by other variables not examined in this study.
\end{abstract}

Keywords: family economy, learning motivation, and learning achievement.

\section{ABSTRAK}

Penelitian ini dilatarbelakangi Kondisi Ekonomi Keluarga, Motivasi Belajar, dan Prestasi Belajar Siswa. Tujuan dari penelitian ini adalah untuk menganalisis mengenai pengaruh Kondisi 


\section{As-Syari: Jurnal Binbingan E̊ Konseling Keluarega}

Ekonomi Keluarga dan Motivasi Belajar Terhadap Prestasi Belajar Siswa Pada Mata Pelajaran Kewirausahaan Kelas XII di SMK Teknomedika 2 Cibungbulang Bogor. Penelitian ini dilakukan menggunakan sampel 42 siswa, menggunakan teknik sampling random dari populasi berjumlah 140 siswa, terdiri dari variabel bebas (independent) kondisi ekonomi keluarrga $\left(\mathrm{X}_{1}\right)$, motivasi belajar $\left(\mathrm{X}_{2}\right)$ dan variabel terikat (dependent) prestasi belajar siswa $(\mathrm{Y})$. Peneliti menggunakan analisis data kuantitatif, tahap pelaksananan analisis meliputi : (1) analisis deskriptif, (2) uji asumsi klasik (prasyarat) dan (3) uji hipotesis..Hasil penelitian ini menunjukkan bahwa : 1) Terdapat pengaruh yang signifikan ekonomi keluarga terhadap prestasi belajar siswa di SMK Teknomedika 2 Cibungbulang Bogor sebesar 50,7\%. 2) Terdapat pengaruh yang signifikan motivasi belajar terhadap prestasi belajar siswa di SMK Teknomedika 2 Cibungbulang Bogor sebesar $51,0 \%$. 3) Terdapat pengaruh yang signifikan antara ekonomi keluarga dan motivasi belajar secara bersama-sama terhadap prestasi belajar siswa di SMK Teknomedika 2 Cibungbulang Bogor sebesar $69,7 \%$ sedangkan sisanya 30,3\% dipengaruhi oleh variabel-variabel lain yang tidak diteliti dalam penelitian ini.

Kata kunci : ekonomi keluarga, motivasi belajar, dan prestasi belajar.

\section{A. PENDAHULUAN}

\section{Latar Belakang}

Berdasarkan UU No. 20 Tahun 2003 pendidikan adalah usaha sadar dan terencana untuk mewujudkan suasana belajar dan proses pembelajaran agar peserta didik secara aktif mengembangkan potensi dirinya untuk memiliki kekuatan spiritual keagamaan, pengendalian diri, kepribadian, kecerdasan, akhlak mulia serta keterampilan yang diperlukan dirinya, masyarakat, bangsa, dan negara (Depdiknas, Undang-Undang RI No. 20 Tahun 2003).

Al Qur'an, menurut Sitti Salmiah Dahlan (2011), memberikan derajat yang tinggi bagi orang-orang yang menuntut ilmu pengetahuan, sebagaimana disebutkan dalam Q.S. Al Mujadalah, $58: 11$.

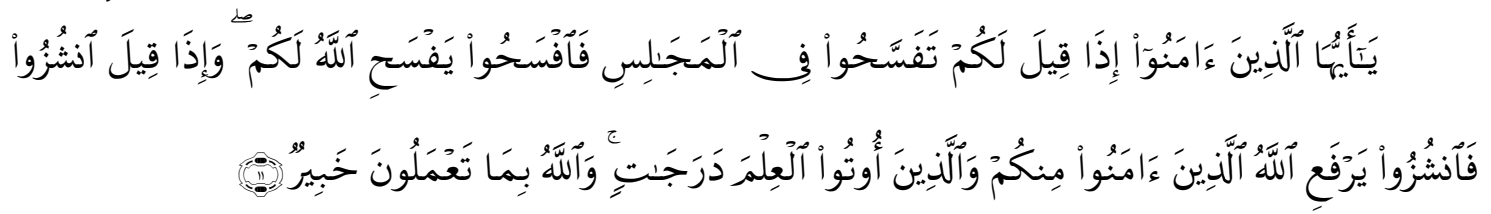

Artinya : "Hai orang-orang beriman apabila dikatakan kepadamu: "Berlapanglapanglah dalam majlis", maka lapangkanlah niscaya Allah akan memberi kelapangan untukmu. Dan apabila dikatakan: "Berdirilah kamu", maka berdirilah, niscaya Allah akan meninggikan orang-orang yang beriman di antaramu dan orang-orang yang diberi ilmu pengetahuan beberapa derajat. Dan Allah Maha Mengetahui apa yang kamu kerjakan."

Uang yang dikeluarkan di bidang pendidikan sebagai bentuk investasi pada periode tertentu, di masa yang akan datang harus dapat menghasilkan keuntungan (benefit) atau manfaat, baik dalam bentuk uang (financial) maupun nonfinansial. Dalam bentuk uang yang diperoleh sebagai balas jasa atas produktivitas tenaga kerja dan dalam bentuk nonfinansial nilai-nilai, seperti meningkatkan kesehatan, keamanan, atau ketertiban masyarakat, baik dari aspek individu, sosial, maupun ekonomi. Untuk memenuhi tuntutan ini para pendidik dan para perencana harus memikirkan tenaga kerja, merencanakan dan 


\section{As-Syari: Jurnal Binbingan E̊ Konseling Keluarega}

menguasai penerimaan murid kemudian output lulusan atau hasilnya supaya sesuai dengan pola kemasyarakatan yang telah dibenarkan oleh para ahli ekonomi dan pengambilan keputusan (Udin Syaefudin Saud, 2005).

Keluarga adalah kelompok primer yang berperan penting didalam membentuk kondisi dalam sebuah masyarakat (Abu Ahmadi, 1991). Maka untuk membentuk lingkungan masyarakat yang baik harus dimulai dari lingkungan keluarga.

Pada buku yang diterbitkan oleh Badan Kependudukan dan Keluarga Berencana Nasional (BKKBN) tentang 8 (delapan) Fungsi Keluarga salah satunya adalah fungsi ekonomi yang membahas dan menganalisa tentang perilaku ekonomi yang dikaitkan dengan proses permintaan dan pemenuhan kebutuhan ekonomi keluarga melalui berbagai jenis dan macam barang-barang maupun jasa untuk memenuhi kebutuhannya baik primer, sekunder atau tersier. (BKKBN, 2012)

Masalah lain yang ditemukan antara lain masih rendahnya motivasi belajar siswa itu sendiri, padahal bahwa keberhasilan pendidikan akan dipengaruhi juga motivasi belajar. Kenyataan yang senantiasa ada bahwa rendahnya motivasi belajar akan dipengaruhi oleh faktor-faktor tumbuhnya motivasi itu sendiri. Di kalangan siswa saat ini masih rendahnya tingkat kesadaran pada dirinya untuk membangkitkan semangat belajar, sehingga prestasi pendidikan yang dicapai belum merata di sekolah-sekolah.

Sekolah SMK TEKNOMEDIKA 2 Cibungbulang Bogor adalah sekolah yang berada di Kp. Galuga Rt. 01/01 Ds. Galuga Kec. Cibungbulang Kabupaten Bogor, berdiri sejak tahun 2013 peneliti menganggap bahwa sekolah tersebut merupakan sekolah yang banyak diminati oleh masyarakat sekitar, karena dari penerimaan peserta didik baru (PPDB) tiga tahun terakhir mengalami peningkatan jumlah siswa serta didukung dengan fasilitas bangunan yang sangat menunjang, akses ke lokasi yg mudah dijangkau oleh peserta didik. Suasana belajar yang sejuk karena berada di area pemukiman tak padat penduduk dan area perkebunan penduduk sekitar.

Terdapat 2 (dua) Kelompok Program Keahlian yaitu 1). Kesehatan dan Pekerjaan Sosial dengan Kompetensi Keahlian Teknologi Laboratorium Medik (TLM) dan Farmasi Klinis dan Komunitas. 2). Bisnis Manajemen dengan Kompetensi Keahlian Akuntansi dan Keuangan Lembaga serta Perbankan dan Keuangan Mikro. Semua kompetensi keahlian sudah terakreditasi peringkat B (Baik).

\section{Rumusan Masalah}

Berdasarkan uraian latar belakang masalah di atas, maka permasalahan dalam penelitian ini dapat dirumuskan sebagai berikut:

1. Apakah terdapat pengaruh kondisi ekonomi keluarga terhadap prestasi belajar siswa pada mata pelajaran Kewirausahaan kelas XII di SMK Teknomedika 2 Cibungbulang Bogor?

2. Apakah terdapat pengaruh motivasi belajar terhadap prestasi belajar siswa pada mata pelajaran Kewirausahaan kelas XII di SMK Teknomedika 2 Cibungbulang Bogor?

3. Apakah terdapat pengaruh kondisi ekonomi keluarga dan motivasi belajar terhadap prestasi siswa pada mata pelajaran Kewirausahaan kelas XII di SMK Teknomedika 2 Cibungbulang Bogor? 


\section{As-Syari: Jurnal Bimbingan É Konseling Keluarga}

\section{Tujuan Penelitian}

Berdasarkan rumusan masalah di atas, tujuan yang ingin dicapai dalam penelitian ini adalah:

1. Untuk mengetahui pengaruh kondisi ekonomi keluarga terhadap prestasi belajar siswa pada mata pelajaran Kewirausahaan kelas XII di SMK Teknomedika 2 Cibungbulang Bogor?

2. Untuk mengetahui pengaruh motivasi belajar terhadap prestasi belajar siswa pada mata pelajaran Kewirausahaan kelas XII di SMK Teknomedika 2 Cibungbulang Bogor?

3. Untuk mengetahui pengaruh ekonomi keluarga dan motivasi belajar terhadap prestasi belajar siswa pada mata pelajaran Kewirausahaan kelas XII di SMK Teknomedika 2 Cibungbulang Bogor?

\section{B. TINJAUAN LITERATUR}

\section{Kerangka Pemikiran}

Permasalahan pada penelitian ini yaitu variabel kondisi ekonomi keluarga $\left(\mathrm{X}_{1}\right)$, variabel motivasi belajar $\left(\mathrm{X}_{2}\right)$ dan variabel prestasi belajar siswa $(\mathrm{Y})$. Adapun kerangka pemikiran digambarkan pada diagram berikut ini.

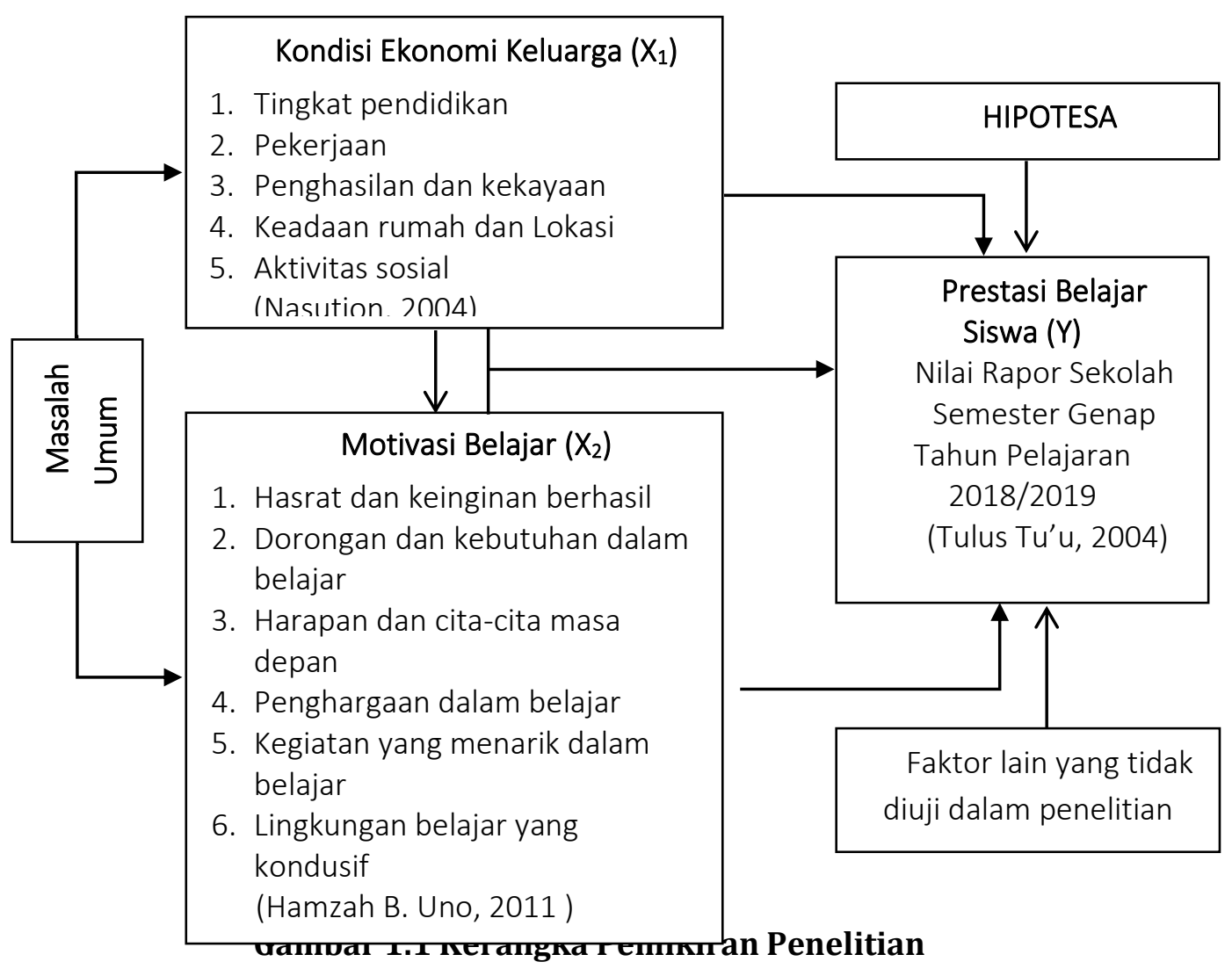

\section{Ekonomi Keluarga}




\section{As-Syari: Jurnal Bimbingan E̊ Konseling Keluargan}

Keluarga merupakan keharusan yang diwajibkan oleh Agama, salah satunya tertera pada Kitab Suci Al Qur'an Firman Allah dalam Surat At-Tahrim Ayat 6:

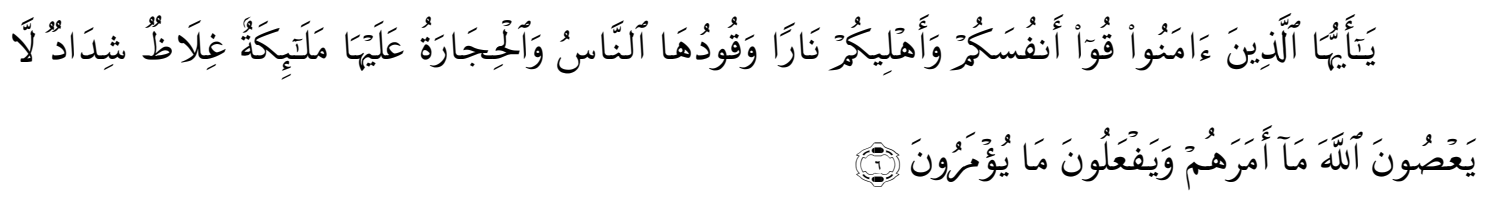

Artinya : "Hai orang-orang yang beriman, peliharalah dirimu dan keluargamu dari api neraka yang bahan bakarnya adalah manusia dan batu; penjaganya malaikat-malaikat yang kasar, yang keras, yang tidak mendurhakai Allah terhadap apa yang diperintahkanNya kepada mereka dan selalu mengerjakan apa yang diperintahkan".

\section{Faktor-faktor yang Mempengaruhi Kondisi Ekonomi Orang Tua}

Menurut Nasution (2004) tingkat status sosial ekonomi dilihat atau diukur dari pekerjaan orang tua, penghasilan dan kekayaan, tingkat pendidikan orang tua, keadaan rumah dan lokasi, pergaulan dan aktivitas sosial.

Soejanto (2002) mengemukakan bahwa kemiskinan atau karena terlalu besarnya jumlah keluarga sering pula menyebabkan kita sulit untuk mendapatkan kesempatan belajar dengan baik. Mungkin karena faktor waktu, faktor tempat maupun faktor penerangan". Sebuah keluarga yang memiliki tanggungan keluarga lebih banyak mempengaruhi terhadap prestasi belajar bilamana ekonomi keluarga kurang memadai.

Dalyono (2009) mengatakan bahwa faktor orang tua sangat besar pengaruhnya terhadap keberhasilan anak dalam belajar. Tinggi rendahnya pendidikan orang tua, besar kecilnya penghasilan (perekonomian orang tua), cukup atau kurang perhatian dan bimbingan orang tua, rukun atau tidaknya kedua orang tua, akrab atau tidaknya hubungan orang tua dengan anak-anak, tenang atau tidaknya situasi dalam rumah, semuanya itu turut mempengaruhi pencapaian hasil belajar anak.

Faktor keadaan rumah juga turut mempengaruhi keberhasilan belajar. Besar kecilnya rumah tempat tinggal, ada atau tidaknya peralatan/media belajar seperti papan tulis, gambar, peta, ada atau tidaknya kamar atau meja belajar, dan sebagainya, semua itu juga turut menentukan keberhasilan belajar seseorang (Dalyono, 2009).

Dari beberapa pendapat tersebut dapat disimpulkan bahwa indikator status sosial ekonomi orang tua antara lain meliputi tingkat pendidikan orang tua, tingkat penghasilan orang tua, jenis pekerjaan orang tua, fasilitas khusus dan barang-barang berharga yang dimiliki serta jabatan sosial orang tua di masyarakat dan dengan uraian sebagai berikut:

\section{Pendidikan}

Pendidikan menurut Kamus Bahasa Indonesia (2007: 263) adalah "Proses pengubahan sikap dan tingkah laku seseorang atau kelompok orang dalam usaha mendewasakan manusia melalui upaya pengajaran dan pelatihan, proses, perbuatan, cara, serta perbuatan mendidik." (Hasan Alwi, 2007). Dalam penelitian ini pendidikan yang dimaksud adalah pendidikan yang ditempuh oleh orang tua melalui jalur pendidikan formal. Pendidikan formal ini terdiri atas pendidikan dasar, menengah, dan pendidikan tinggi. Pendidikan yang dimiliki orang tua akan ikut menentukan perkembangan pribadi dan pembentukan sikap dari anaknya.

Penghasilan 


\section{As-Syari: Jurnal Binbingan E̊ Konseling Keluarega}

Penghasilan menurut Kamus Besar Bahasa Indonesia (2007: 392) adalah "Proses, cara, perbuatan menghasilkan, pendapatan, perolehan (uang yang diterima dan sebagainya)" (Hasan Alwi, 2007). Semakin tinggi pendapatan semakin makmur, sejahtera dan dihargai di masyarakat (Suryani, 2008).

\section{Pekerjaan}

Pekerjaan menurut Kamus Bahasa Indonesia adalah "Barang apa yang dilakukan (diperbuat, dipekerjakan dsb); tugas kewajiban, hasil bekerja, perbuatan; pencarian yang dijadikan pokok penghidupan, sesuatu yang dibutuhkan untuk mendapat nafkah; hal bekerjanya sesuatu (Hasan Alwi, 2007). Pekerjaan terkait dengan status sosial masyarakat, Suryani (2008: 268) mengemukakan, "Masyarakat menilai ada pekerjaanpekerjaan tertentu yang prestisius yang menunjukkan kelas sosial atas dan sebaliknya." (Suryani, 2008)

\section{Fasilitas Khusus dan Barang Berharga yang Dimiliki}

Fasilitas khusus dalam hal ini merupakan fasilitas-fasilitas yang dimiliki orang tua, misalnya kendaraan. Barang berharga menurut Kamus Besar Bahasa Indonesia adalah "Barang yang tinggi nilainya dan mahal harganya." (Hasan Alwi, 2007) Barang berharga yang dimiliki seseorang akan membuat lebih terpandang di masyarakatnya. Fasilitas khusus dan barang berharga yang dimiliki orang tua dapat menunjang pendidikan anaknya sehingga dapat menumbuhkan minat anaknya sebagai seorang siswa untuk melanjutkan studi ke Perguruan Tinggi.

\section{Jabatan Sosial}

Jabatan Sosial menurut Kamus Besar Bahasa Indonesia adalah, "Pekerjaan (tugas) di masyarakat yang mengatur hubungan masyarakat." Jabatan sosial orang tua yaitu jabatan yang di pegang oleh orang tua dalam masyarakat (Hasan Alwi, 2007).

Berdasarkan uraian di atas, dari beberapa faktor yang mempengaruhi kondisi ekonomi keluarga, untuk indikator kondisi ekonomi keluarga yang digunakan pada penelitian ini adalah dari indikator kondisi ekonomi keluarga menurut pendapat Nasution, diantaranya pekerjaan orang tua, penghasilan dan kekayaan, tingkat pendidikan orang tua, keadaan rumah dan lokasi, pergaulan dan aktivitas sosial.

\section{Motivasi Belajar}

Al Qur'an Surat Al Baqarah $2: 286$ menerangkan tentang motivasi belajar:

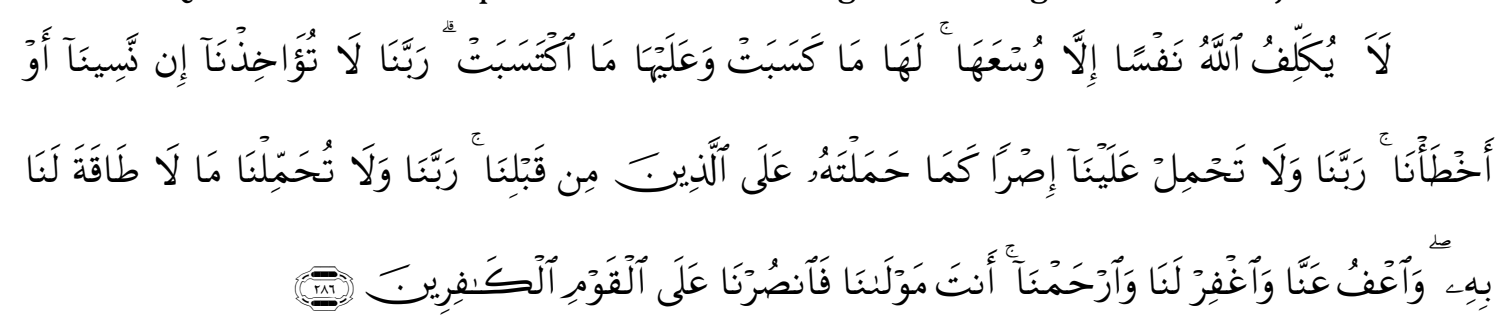

Artinya :"Allah tidak membebani seseorang melainkan sesuai dengan kesanggupannya.ia mendapat pahala (dari kebajikan) yang diusahakannya dan ia mendapat siksa (dari kejahatan) yang dikerjakannya. (mereka berdoa): "Ya Tuhan Kami, 


\section{As-Syari: Jurnal Bimbingan E̊ Konseling Keluargan}

janganlah Engkau hukum Kami jika Kami lupa atau Kami tersalah. Ya Tuhan Kami, janganlah Engkau bebankan kepada Kami beban yang berat sebagaimana Engkau bebankan kepada orang-orang sebelum kami. Ya Tuhan Kami, janganlah Engkau pikulkan kepada Kami apa yang tak sanggup Kami memikulnya. beri ma'aflah kami; ampunilah kami; dan rahmatilah kami. Engkaulah penolong Kami, Maka tolonglah Kami terhadap kaum yang kafir."

Menurut Hamzah (2011) "motivasi merupakan suatu dorongan yang timbul oleh adanya rangsangan dari dalam maupun dari luar sehingga seseorang berkeinginan untuk mengadakan perubahan tingkah laku/ aktivitas tertentu lebih baik dari keadaan sebelumnya".

Menurut Ormrod (2008) "motivasi adalah sesuatu yang menghidupkan (energize), mengarahkan dan mempertahankan perilaku; motivasi membuat siswa bergerak, menempatkan mereka dalam suatu arah tertentu, dan menjaga mereka agar terus bergerak". Syah (2012) mengemukakan bahwa motivasi adalah keadaan internal organisme baik manusia atau hewan yang mendorong untuk melakukan sesuatu.

Martinis Yamin (2006) juga mengatakan bahwa "motivasi belajar merupakan daya penggerak psikis dari dalam diri seseorang untuk dapat melakukan kegiatan belajar dan menambah keterampilan, pengalaman".

Berdasarkan pendapat teori para ahli di atas, dapat disimpulkan bahwa bahwa motivasi belajar adalah daya penggerak seseorang yang dapat berasal dari dalam maupun luar diri siswa yang menyebabkan mereka bertindak secara nyata untuk belajar agar dapat mencapai tujuan pembelajaran yang diharapkan.

\section{Jenis-jenis Motivasi}

Hamzah ((2011) menjelaskan perbedaan motivasi ekstrinsik dan motivasi instrinsik. Motivasi ekstrinsik berisi: (1) Penyesuaian tugas dengan minat, (2) Perencanaan yang penuh dengan variasi, (3) Respon siswa, (4) Kesempatan peserta didik yang aktif, (5) Kesempatan peserta didik untuk menyesuaikan tugas pekerjaannya, dan (6) Adanya kegiatan yang menarik dalam belajar. Sedangkan motivasi instrinsik berisi: (1) Penyesuaian tugas dengan minat, (2) Perencanaan yang penuh dengan variasi, (3) Umpan balik atas respon siswa, (4) Kesempatan respons peserta didik yang aktif, dan (5) Kesempatan peserta didik untuk menyesuaikan tugas pekerjaannya.

\section{Fungsi Motivasi}

Prawira mengemukakan bahwa fungsi motivasi meliputi :

1) Motivasi itu bersifat mengarahkan dan mengatur tingkah laku individu. Dengan demikian motivasi di pastikan memiliki tujuan, mengandung kekuatan dan kegigihan untuk melakukan tindakan.

2) Motivasi sebagai penyeleksi tingkah laku individu. Motif ini bertindak agar individu terarah kepada suatu tujuan yang di pilih (diminati)

3) Motif memberi energi dan menahan tingkah laku individu. Motif ini memiliki fungsi mempertahankan agar perubahan atau minat dapat berlangsung terus menerus dalam jangka waktu lama. (Prawira, 2013)

Menurut Oemar Hamalik fungsi motivasi belajar adalah sebagai berikut:

1) Mendorong timbulnya kelakuan atau suatu perbuatan. Tanpa motivasi tidak akan timbul perbuatan seperti belajar. 


\section{As-Syari: Jurnal Binbingan E̊ Konseling Keluarega}

2) Sebagai pengarah, artinya mengarahkan perbuatan kepada pencapaian tujuan yang diinginkan.

3) Sebagai penggerak. Ia akan berfungsi sebagai mesin bagi mobil. Besarnya motivasi akan menetukan cepat atau lambatnya suatu pekerjaan. (Oemar Hamalik, 2008)

Dari uraian di atas, di simpulkan bahwa fungsi motivasi belajar adalah mengarahkan perbuatan siswa dan menimbulkan kegiatan siswa untuk mengarahkan perbuatan yang mencapai tujuan dan memilih atau menyeleksi suatu perbuatan untuk mencapai kegiatan belajar. Motivasi belajar bukan saja penting karena menjadi faktor penyebab belajar, namun juga memaksimalkan hasil belajar. Hasil belajar akan menjadi maksimal jika ada motivasi belajar. Semakin tinggi motivasi belajar yang dimiliki, maka semakin maksimal hasil belajar yang didapat oleh siswa.

\section{Faktor-faktor yang Mempengaruhi Motivasi Belajar}

Menurut Uno, indikator motivasi belajar dapat diklasifikasikan sebagai berikut :

1) Adanya hasrat dan keinginan berhasil

2) Adanya dorongan dan kebutuhan dalam belajar

3) Adanya harapan dan cita-cita masa depan

4) Adanya penghargaan dalam belajar

5) Adanya kegiatan yang menarik dalam belajar

6) Adanya lingkungan belajar yang kondusif. (Hamzah, 2011)

\section{Prestasi Belajar}

Al Qur'an Surat Al An'aam 6:160 menerangkan tentang prestasi belajar :

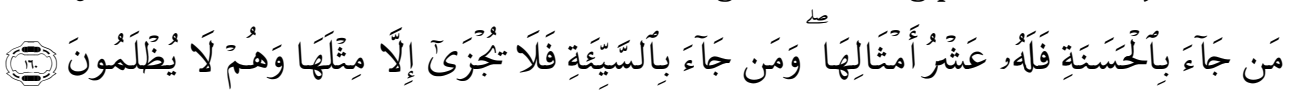

Artinya :"Barangsiapa membawa amal yang baik, Maka baginya (pahala) sepuluh kali lipat amalnya; dan Barangsiapa yang membawa perbuatan jahat Maka Dia tidak diberi pembalasan melainkan seimbang dengan kejahatannya, sedang mereka sedikitpun tidak dianiaya (dirugikan)."

Dari beberapa teori di atas tentang pengertian prestasi belajar, maka prestasi belajar yang dimaksud dalam penelitian ini adalah prestasi belajar menurut Tulus Tu'u pada aspek kognitif setelah siswa selesai melaksanakan proses pembelajaran yaitu nilai rapor mata pelajaran kewirausahaan tahun pelajaran 2018/2019.

Tulus Tu'u mendefinisikan prestasi belajar siswa sebagai berikut:

Prestasi belajar siswa adalah hasil belajar yang dicapai siswa ketika mengikuti dan mengerjakan tugas dan kegiatan pembelajaran di sekolah.

Prestasi belajar siswa tersebut terutama dinilai aspek kognitifnya karena bersangkutan dengan kemampuan siswa dalam pengetahuan atau ingatan, pemahaman, aplikasi, analisis, sintesa dan evaluasi.

Prestasi belajar siswa. Menurut Tu'u (2004), dibuktikan dan ditunjukan melalui nilai atau angka nilai dari hasil evaluasi yang dilakukan oleh guru terhadap tugas siswa dan ulangan-ulangan atau ujian yang ditempuhnya.

\section{Faktor-faktor yang Mempengaruhi Prestasi Belajar}




\section{As-Syari: Jurnal Bimbingan E̊ Konseling Keluargan}

Abu Ahmadi dan Supriyono berpendapat bahwa faktor yang mempengaruhi prestasi belajar siswa dilihat dari faktor dalam diri (faktor internal) dan faktor dari luar diri (faktor internal) individu. Berikut penjelasannya:

Faktor internal terdiri dari:

Faktor jasmaniah (fisiologis) baik yang bersifat bawaan ataupun yang diperoleh. Yang termasuk faktor ini misalnya penglihatan, pendengaran struktur tubuh dan sebagainya.

Faktor psikologis baik yang bersifat bawaan maupun yang diperoleh, yang terdiri atas:

1) Faktor intelektif yang meliputi:

2) Faktor potensial, yaitu kecerdasan dan bakat

3) Faktor kecakapan yang nyata yaitu prestasi yang dimiliki.

Faktor non intelektif, yaitu unsur-unsur kepribadian tertentu seperti sikap, minat, kebiasaan, motivasi, emosi, kebutuhan dan penyesuaian diri.

Faktor kematangan fisik maupun psikis

Faktor eksternal atau faktor sosial yang terdiri dari:

\section{Lingkungan keluarga}

Salah satu lembaga yang amat menentukan terhadap pembentukan pribadi anak, karena dalam keluarga inilah anak menerima pendidikan dan bimbingan pertama kali dari orangtua dan anggota keluarga lainnya. Di dalam keluarga inilah seorang yang masih dalam usia muda diberikan dasar-dasar kepribadian, karena pada usia ini anak lebih peka terhadap

Pengaruh yang datang dari luar dirinya. Faktor ekonomi keluargapun sangat menentukan, belajar di sekolah baik di desa apalagi di kota tak akan luput dari unsure biaya. Keluarga yang memiliki perekonomian yang memadai akan turut menjamin keberhasilan anak dalam kegiatan belajarnya.

\section{Lingkungan sekolah}

Sekolah merupakan lembaga pendidikan yang amat penting bagi kelangsungan pendidikan anak. Sebab tidak semahal yang dapat diajarkan di lingkungan keluarga karena terbatasnya kemampuan dan pengetahuan yang dimiliki oleh orang tua. Sekolah bertugas sebagai pembantu dalam memberikan pendidikan dan pengajaran kepada anakanak mengenai apa yang tidak didapat atau tidak ada kesempatan orang tua untuk memberikan pendidikans dan pengajaran di dalam keluarga.

\section{Lingkungan masyarakat}

Lingkungan masyarakat meliputi, faktor media massa, pergaulan dan tipe masyarakat.

1) Lingkungan kelompok

2) Faktor budaya, seperti adat istiadat, ilmu pengetahuan, teknologi dan kesenian.

3) Faktor lingkungan fisik, seperti fasilitas rumah, fasilitas belajar, dan iklan

4) Faktor lingkungan spiritual dan keamanan (Abu Ahmad dan Widodo Supriyono, 1991)

Dari paparan di atas dapat disimpulkan bahwa ada dua faktor yang mempengaruhi prestasi belajar siswa, yaitu faktor internal dan eksternal siswa. Kedua faktor ini harus 


\section{As-Syar'i: Jurual Bimbingenan है Konseling Keluargega}

benar-benar jadi perhatian kita sebagai pendidik (guru dan orang tua) dalam proses belajar anak.

\section{Hasil Penelitian Terdahulu Yang Relevan}

Penelitian yang berkaitan dengan judul "Pengaruh Kondisi Ekonomi Keluarga dan Motivasi Belajar Terhadap Prestasi Belajar Siswa Pada Mata Pelajaran Kewirausahaan Kelas XII di SMK Teknomedika 2 Cibungbulang Bogor" ditemukan pada penelitian yang tercantum pada tabel 1.1 berikut ini.

Table 1.1 Hasil Penelitian Terdahulu Yang Relevan

\begin{tabular}{|c|c|c|c|c|}
\hline NO & PENELITIAN & HASIL PENELITIAN & PERSAMAAN & PERBEDAAN \\
\hline 1. & 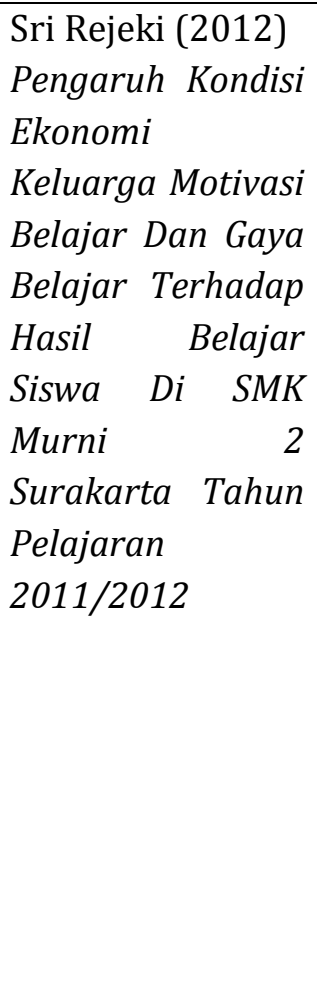 & $\begin{array}{l}\text { (1) terdapat pengaruh } \\
\text { langsung kondisi ekonomi } \\
\text { keluarga terhadap hasil } \\
\text { belajar siswa, (2) terdapat } \\
\text { pengaruh langsung } \\
\text { motivasi belajar terhadap } \\
\text { hasil belajar, (3) terdapat } \\
\text { pengaruh langsung gaya } \\
\text { belajar terhadap hasil } \\
\text { belajar, (4) terdapat } \\
\text { pengaruh tidak langsung } \\
\text { kondisi ekonomi keluarga } \\
\text { terhadap hasil belajar } \\
\text { siswa melalui gaya belajar, } \\
\text { dan (5) terdapat pengaruh } \\
\text { tidak langsung motivasi } \\
\text { belajar terhadap hasil } \\
\text { belajar melalui gaya } \\
\text { belajar. }\end{array}$ & $\begin{array}{lr}1 . & \text { Terdapat } \\
\text { pengaruh yang } \\
\text { signifikan ekonomi } \\
\text { keluarga terhadap } \\
\text { prestasi belajar. } \\
2 . \quad \text { Terdapat } \\
\text { pengaruh yang } \\
\text { signifikan motivasi } \\
\text { belajar terhadap } \\
\text { prestasi belajar. }\end{array}$ & $\begin{array}{lr}\text { Terdapat } & \text { pengaruh } \\
\text { yang } & \text { signifikan } \\
\text { antara } & \text { ekonomi } \\
\text { keluarga } & \text { dan } \\
\text { motivasi } & \text { belajar } \\
\text { secara } & \text { bersama- } \\
\text { sama } & \text { terhadap } \\
\text { prestasi } & \text { belajar } \\
\text { siswa. } & \end{array}$ \\
\hline 2. & 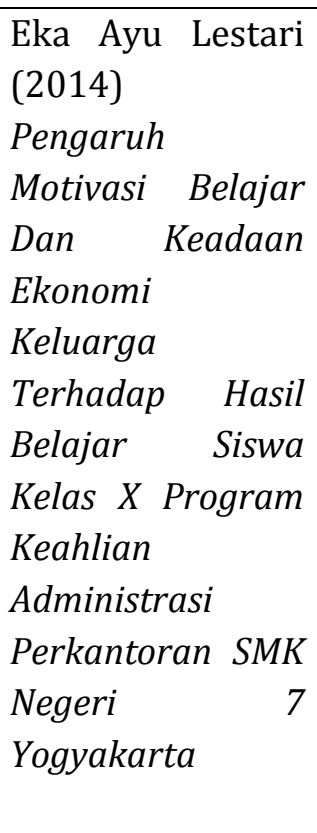 & $\begin{array}{l}\text { (1) terdapat pengaruh } \\
\text { positif dan signifikan } \\
\text { motivasi belajar terhadap } \\
\text { hasil belajar siswa, (2) } \\
\text { terdapat pengaruh yang } \\
\text { positif dan signifikan } \\
\text { keadaan ekonomi keluarga } \\
\text { terhadap hasil belajar } \\
\text { siswa, (3) terdapat } \\
\text { pengaruh yang positif } \\
\text { motivasi belajar dan } \\
\text { keadaan ekonomi keluarga } \\
\text { bersama-sama terhadap } \\
\text { hasil siswa pada taraf } \\
\text { signifikansi } 5 \% \text { dengan n= } \\
55 \text {. }\end{array}$ & $\begin{array}{lr}1 . & \text { Terdapat } \\
\text { pengaruh } & \text { yang } \\
\text { signifikan } & \text { ekonomi } \\
\text { keluarga } & \text { terhadap } \\
\text { prestasi belajar. } \\
2 . \quad \text { Terdapat } \\
\text { pengaruh } \quad \text { yang } \\
\text { signifikan } & \text { motivasi } \\
\text { belajar terhadap } \\
\text { prestasi belajar. } \\
\begin{array}{lr}\text { 3. Terdapat } \\
\text { pengaruh } & \text { yang } \\
\text { signifikan } & \text { antara } \\
\text { ekonomi } & \text { keluarga } \\
\text { dan } & \text { motivasi } \\
\text { belajar } & \text { secara }\end{array}\end{array}$ & \\
\hline
\end{tabular}




\section{As-Syari: Jurnal Bimbingan E̊ Konseling Keluargan}

\begin{tabular}{|c|c|c|c|c|}
\hline & & & $\begin{array}{l}\text { bersama-sama } \\
\text { terhadap prestasi } \\
\text { belajar siswa. }\end{array}$ & \\
\hline 3. & $\begin{array}{l}\text { Masnimawati } \\
\text { (2017) } \\
\text { Pengaruh Latar } \\
\text { Belakang } \\
\text { Ekonomi Orang } \\
\text { Tua Dan Motivasi } \\
\text { Belajar } \\
\text { Mahasiswa } \\
\text { Terhadap Prestasi } \\
\text { Belajar Sejarah } \\
\text { Mahasiswa } \\
\text { Pendidikan } \\
\text { Sejarah } \\
\text { Universitas } \\
\text { Sanata Dharma } \\
\text { Yogyakarta } \\
\text { angkatan } 2013 \\
\text { dan 2014. }\end{array}$ & $\begin{array}{l}\text { (1) tidak ada pengaruh } \\
\text { latar belakang } \text { ekonomi } \\
\text { orang tua terhadap } \\
\text { prestasi belajar sejarah } \\
\text { mahasiswa, (2) tidak ada } \\
\text { pengaruh motivasi belajar } \\
\text { mahasiswa terhadap } \\
\text { prestasi belajar sejarah } \\
\text { mahasiswa, (3) ada } \\
\text { pengaruh secara bersama } \\
\text { antara latar belakang } \\
\text { ekonomi orang tua dan } \\
\text { motivasi } \\
\text { mahasiswa belajar } \\
\text { prestasi belajar sejarah } \\
\text { mahasiswa. }\end{array}$ & $\begin{array}{l}\text { Terdapat pengaruh } \\
\text { yang signifikan antara } \\
\text { ekonomi keluarga dan } \\
\text { motivasi belajar } \\
\text { secara bersama-sama } \\
\text { terhadap prestasi } \\
\text { belajar siswa. }\end{array}$ & $\begin{array}{l}\text { 1) Terdap } \\
\text { at pengaruh } \\
\text { yang signifikan } \\
\text { ekonomi } \\
\text { keluarga } \\
\text { terhadap } \\
\text { prestasi belajar. } \\
\text { 2) } \quad \text { Terdap } \\
\text { at pengaruh } \\
\text { yang signifikan } \\
\text { motivasi belajar } \\
\text { terhadap } \\
\text { prestasi belajar. }\end{array}$ \\
\hline
\end{tabular}

Dari ketiga penelitian terdahulu yang relevan dengan penelitian ini, dapatlah diketahui bahwa variabel dependent (terikat) dan independent (bebas) di sini adalah sama-sama prestasi/hasil belajar siswa. Jadi posisi penelitian ini memperluas variabel yang mempengaruhi prestasi/hasil belajar siswa penelitian yang terdahulu.

\section{METODE PENELITIAN}

Sehubungan dengan permasalahan yang diangkat oleh peneliti yaitu "Pengaruh Kondisi Ekonomi Keluarga dan Motivasi Belajar Terhadap Prestasi Belajar Siswa Pada Mata Pelajaran Kewirausahaan Kelas XII di SMK Teknomedika 2 Cibungbulang Bogor", maka peneliti menggunakan metode penelitian kuantitatif, karena data penelitian yang dihasilkan berupa angka-angka dan dianalisis dengan menggunakan statistik. Hal ini sesuai dengan pendapat Suharsimi Arikunto (2002) yang mengemukakan penelitian kuantitatif adalah pendekatan penelitian yang banyak dituntut menggunakan angka, mulai dari pengumpulan data, penafsiran terhadap data tersebut, serta penampilan hasilnya.

Tempat yang dijadikan lokasi penelitian adalah di SMK Teknomedika 2 Cibungbulang yang beralamat di Jl. Galuga Rt. 001/001 Kecamatan Cibungbulang Kabupaten Bogor. Waktu kegiatan penelitian ini dilaksanakan mulai dari bulan April sampai dengan Juni 2018.

Populasi dalam penelitian ini adalah seluruh siswa kelas XII di SMK Teknomedika 2 Cibungbulang Bogor, yang berjumlah 140 siswa. Mengacu pada pendapat S. Arikunto, 


\section{As-Syari: Jurnal Binbingan E̊ Konseling Keluarega}

peneliti mengambil sampel sebanyak 30\% dari jumlah populasi (140 siswa), jadi jumlah sampel dalam penelitian ini adalah $30 \%$ x $140=42$ siswa.

Teknik pengumpulan data yang digunakan peneliti adalah (1) Metode Angket (Kuesioner), angket disusun peneliti berdasarkan pada variabel yang akan diteliti, yang terdiri dari 20 item pertanyaan tentang kondisi ekonomi keluarga dan 25 item pernyataan tentang motivasi belajar siswa yang mana tiap item tersebut disediakan 5 (lima) alternatif jawaban sesuai dengan skala likert. (2) Metode Dokumentasi dengan cara mengumpulkan data prestasi belajar siswa yang diambil dari nilai rata-rata raport mata pelajaran Kewirausahaan setiap siswa kelas XII di SMK Teknomedika 2 Cibungbulang Bogor tahun pelajaran 2018/2019.

Teknik Analisa Data dalam penelitian ini menggunakan teknis analisis data regresi sederhana dan regresi berganda dengan bantuan software SPSS windows versi 17 dan microsoft excel 2010. SPSS adalah singkatan dari Statistical Package for the Sosial Sciences. Namun sekarang SPSS diperluas untuk melayani berbagai user, seperti untuk proses produksi di pabrik, riset ilmu-ilmu sains dan lainnya. Sekarang kepanjangan SPSS adalah Statistical Product and Service Solutions (2018). Adapun tahap pelaksananan analisis meliputi : (1) analisis deskriptif, (2) uji asumsi klasik (prasyarat), dan (3) uji hipotesis.

\section{HASIL PENELITIAN DAN PEMBAHASAN}

Setelah dilakukan perhitungan dan analisis terhadap hipotesis penelitian ini, maka dilakukan pembahasan terhadap hasil penelitian tersebut. Adapun pembahasan penelitian ini adalah sebagai berikut:

\section{Pengaruh Ekonomi Keluarga Terhadap Prestasi Belajar Siswa}

Hipotesis penelitian pertama adalah terdapat pengaruh ekonomi keluarga terhadap prestasi belajar siswa di SMK Teknomedika 2 Cibungbulang Bogor. Berikut rumusan hipotesisnya :

H0 : Tidak terdapat pengaruh yang signifikan ekonomi keluarga terhadap prestasi belajar siswa di SMK Teknomedika 2 Cibungbulang Bogor

H1 : Terdapat pengaruh yang signifikan ekonomi keluarga terhadap prestasi belajar siswa di SMK Teknomedika 2 Cibungbulang Bogor

Tabel 4.12 Hasil Analisis Regresi dan Uji t Ekonomi Keluarga terhadap Prestasi Belajar Siswa

Coefficients $^{\mathbf{a}}$

\begin{tabular}{|l|l|l|l|l|l|}
\hline \multirow{2}{*}{ Model } & \multicolumn{2}{|l|}{$\begin{array}{l}\text { Unstandardized } \\
\text { Coefficients }\end{array}$} & $\begin{array}{l}\text { Standardized } \\
\text { Coefficients }\end{array}$ & t & \multirow{2}{*}{ Sig. } \\
\cline { 2 - 4 } & $\mathrm{B}$ & Std. Error & Beta & & \\
\hline $1 \quad$ (Constant $)$ & 61.772 & 2.744 & & 22.514 & 0.000 \\
\hline
\end{tabular}




\section{As-Syari: Jurnal Bimbingan E̊ Konseling Keluargan}

\begin{tabular}{|l|l|l|l|l|l|}
\hline Ekonomi & 0.326 & 0.051 & 0.712 & 6.417 & 0.000 \\
Keluarga $\left(\mathrm{X}_{1}\right)$ & 0.326 &
\end{tabular}

a. Dependent Variable: Prestasi Belajar Siswa

Berdasarkan hasil analisis regresi dan uji t pada tabel 4.12 di atas, diperoleh nilai Sig untuk variabel ekonomi keluarga sebesar 0,000 dan nilai $t_{\text {hitung }}=22,514$. Dengan taraf nyata $5 \%$ dan derajat kepercayaan ( $\mathrm{df}=\mathrm{n}-2)=42-2=40$, maka diperoleh nilai $t_{\text {tabel }}=2,021$. Karena nilai Sig $=0,000<0,05$ dan $t_{\text {hitung }}>t_{\text {tabel }}(22,514$ $>2,021$ ), maka $\mathrm{H}_{0}$ ditolak dan $\mathrm{H}_{1}$ diterima yang berarti terdapat pengaruh yang signifikan ekonomi keluarga terhadap prestasi belajar siswa.

Berdasarkan output di atas diperoleh koefisien regresi sebesar 0,326 dan konstanta sebesar 61,772. Maka dapat digambarkan bentuk hubungan variabel ekonomi keluarga dengan prestasi belajar siswa dalam bentuk persamaan regresi $Y$ $=61,772+0,326 \mathrm{X}_{1}$. Ini berarti bahwa jika ekonomi keluarga meningkat sebesar 1 poin maka prestasi belajar siswa akan meningkat sebesar 0,326 poin pada konstanta 61,772. Dengan kata lain bahwa semakin baik ekonomi keluarga maka prestasi belajar siswa akan meningkat pula.

Besarnya pengaruh ekonomi keluarga terhadap prestasi belajar siswa dihitung dengan bantuan program SPSS versi 17 . Hasil perhitungannya dapat dilihat pada tabel 4.13 di bawah ini:

Tabel 4.13 Koefisien Determinasi Ekonomi Keluarga Terhadap Prestasi Belajar Siswa

\begin{tabular}{|l|l|l|l|l|l|}
\hline Model & $\mathrm{R}$ & R Square & $\begin{array}{l}\text { Adjusted } \\
\text { Square }\end{array}$ & $\begin{array}{l}\text { Std. Error of the } \\
\text { Estimate }\end{array}$ \\
\hline 1 & $0.712^{\mathrm{a}}$ & 0.507 & 0.495 & 2.599 \\
\hline
\end{tabular}

a. Predictors: (Constant), Ekonomi Keluarga

b. Dependent Variable: Prestasi Belajar Siswa

Berdasarkan output program SPSS di atas, diperoleh nilai korelasi ekonomi keluarga terhadap prestasi belajar siswa sebesar 0,712 dan nilai $\mathrm{R}$ square sebesar 0,507 atau 50,7\%. Hal ini berarti bahwa variabel ekonomi keluarga berpengaruh terhadap prestasi belajar siswa sebesar 50,7\%, dan sisanya sebesar 49,3\% ditentukan oleh faktor lain diluar model regresi tersebut.

Berdasarkan hasil analisis tersebut, dapat disimpulkan bahwa hipotesis penelitian pertama diterima $\left(\mathrm{H}_{0}\right.$ ditolak dan $\mathrm{H}_{1}$ diterima), yang artinya terdapat pengaruh yang signifikan ekonomi keluarga terhadap prestasi belajar siswa di SMK Teknomedika 2 Cibungbulang Bogor .

Hasil analisis tersebut diperkuat oleh beberapa teori, salah satunya menurut Soejanto (2008) yang mengemukakan bahwa kemiskinan atau karena terlalu besarnya jumlah keluarga sering pula menyebabkan kita sulit untuk mendapatkan kesempatan belajar dengan baik. Mungkin karena faktor waktu, faktor tempat maupun faktor penerangan". Sebuah keluarga yang memiliki tanggungan keluarga lebih banyak mempengaruhi terhadap prestasi belajar bilamana ekonomi keluarga kurang memadai. 


\section{As-Syari: Jurnal Binbingan E̊ Konseling Keluarega}

Pendapat ahli yang lain seperti Dalyono (2013) mengatakan bahwa faktor orang tua sangat besar pengaruhnya terhadap keberhasilan anak dalam belajar. Tinggi rendahnya pendidikan orang tua, besar kecilnya penghasilan (perekonomian orang tua), cukup atau kurang perhatian dan bimbingan orang tua, rukun atau tidaknya kedua orang tua, akrab atau tidaknya hubungan orang tua dengan anak-anak, tenang atau tidaknya situasi dalam rumah, semuanya itu turut mempengaruhi pencapaian hasil belajar anak.

Di samping mendukung teori yang ada, penelitian ini juga didukung dengan hasil penelitian sebelumnya yang menjadi referensi dari penelitian ini yang menyatakan bahwa terdapat pengaruh motivasi belajar terhadap prestasi belajar siswa.

\section{Pengaruh Motivasi belajar Terhadap Prestasi Belajar Siswa}

Hipotesis kedua penelitian ini adalah terdapat pengaruh motivasi belajar terhadap prestasi belajar siswa di SMK Teknomedika 2 Cibungbulang Bogor. Berikut rumusan hipotesisnya :

$\mathrm{H}_{0} \quad$ : Tidak terdapat pengaruh yang signifikan motivasi belajar terhadap prestasi belajar siswa di SMK Teknomedika 2 Cibungbulang Bogor.

$\mathrm{H}_{1}$ : Terdapat pengaruh yang signifikan motivasi belajar terhadap prestasi belajar siswa di SMK Teknomedika 2 Cibungbulang Bogor.

Hasil perhitungan analisis regresi linear sederhana dan uji t pengaruh motivasi belajar terhadap prestasi belajar siswa dengan menggunakan program SPSS versi 17 dapat dilihat pada tabel 4.14 di bawah ini:

Tabel 4.14 Hasil Analisis Regresi dan Uji t Motivasi Belajar Terhadap Prestasi Belajar Siswa

\section{Coefficients}

\begin{tabular}{|ll|l|l|l|l|l|}
\hline \multirow{2}{*}{ Model } & \multicolumn{2}{|l|}{$\begin{array}{l}\text { Unstandardized } \\
\text { Coefficients }\end{array}$} & $\begin{array}{l}\text { Standardized } \\
\text { Coefficients }\end{array}$ & T & \multirow{2}{*}{ Sig. } \\
\cline { 2 - 5 } & $\mathrm{B}$ & Std. Error & Beta & & \\
\hline 1 & $\begin{array}{l}\text { (Constant) } \\
\begin{array}{l}\text { Motivasi belajar } \\
\left(\mathrm{X}_{2}\right)\end{array}\end{array}$ & 31.853 & 7.349 & & 0.334 & 0.000 \\
\hline
\end{tabular}

a. Dependent Variable: Prestasi Belajar Siswa

Berdasarkan hasil perhitungan yang telah dilakukan diketahui bahwa persamaan regresi motivasi belajar terhadap prestasi belajar siswa yaitu $\mathrm{Y}=31,853+0,484 \mathrm{X}_{2}$. Nilai persamaan tersebut adalah positif, artinya terdapat pengaruh motivasi belajar terhadap prestasi belajar siswa. Selanjutnya untuk mengetahui tingkat signifikansinya dilakukan uji $t$, nilai $t_{\text {hitung }}>t_{\text {tabel }}(4,334>2,021)$ dan nilai Signifikansi sebesar 0,000 $<0,05$. Jadi hipotesis penelitian kedua diterima $\left(\mathrm{H}_{0}\right.$ ditolak dan $\mathrm{H}_{1}$ diterima), yang artinya terdapat pengaruh yang signifikan motivasi belajar $\left(\mathrm{X}_{2}\right)$ terhadap prestasi belajar siswa $(\mathrm{Y})$ di SMK Teknomedika 2 Cibungbulang Bogor . 


\section{As-Syari: Jurnal Bimbingan Ę Konseling Keluarga}

Tabel 4.15 Koefisien Determinasi Motivasi Belajar Terhadap Prestasi Belajar Siswa

\begin{tabular}{|l|l|l|l|l|}
\hline Model & $\mathrm{R}$ & R Square & $\begin{array}{l}\text { Adjusted } \\
\text { Square }\end{array}$ & $\begin{array}{l}R \\
\text { Std. Error of the } \\
\text { Estimate }\end{array}$ \\
\hline 1 & $0.714^{\mathrm{a}}$ & 0.510 & 0.498 & 2.592 \\
\hline
\end{tabular}

a. Predictors: (Constant), Motivasi belajar $\left(\mathrm{X}_{2}\right)$

b. Dependent Variable: Prestasi belajar siswa (Y)

Untuk mengetahui seberapa besar pengaruh motivasi belajar terhadap prestasi belajar siswa, maka dilakukan uji koefisien determinasi. Pada uji determinasi ini diperoleh nilai R square sebesar 0,510 atau 51,0\%. Hal ini berarti bahwa variabel motivasi belajar berpengaruh terhadap prestasi belajar siswa sebesar $51,0 \%$.

Berdasarkan hipotesis penelitian kedua yang menyatakan bahwa motivasi belajar berpengaruh terhadap prestasi belajar siswa adalah terbukti. Hal ini menjelaskan bahwa apabila kondisi motivasi belajar mendukung proses belajar siswa, maka motivasi belajar akan mampu meningkatkan prestasi belajar siswa.

Penelitian ini mendukung beberapa teori yang ada, seperti teori yang dikemukakan oleh Hamdani dan Zainal Akib (2012), faktor-faktor yang mempengaruhi hasil belajar (prestasi belajar) dapat digolongkan menjadi dua bagian, yaitu faktor dari dalam (intern) dan faktor dari luar (ekstern). Salah satu faktor internal yang mempengaruhi prestasi belajar adalah motivasi belajar.

Martinis Yamin (2009) juga mengatakan bahwa "motivasi belajar merupakan daya penggerak psikis dari dalam diri seseorang untuk dapat melakukan kegiatan belajar dan menambah keterampilan, pengalaman."

Motivasi belajar yang tinggi akan meningkatkan prestasi belajar karena belajar dengan motivasi akan mendorong siswa belajar lebih baik dan memperoleh hasil yang baik pula dibandingkan dengan belajar tanpa adanya motivasi. Dengan demikian dapat dikatakan bahwa semakin tinggi motivasi belajar yang dimiliki siswa maka hasil yang diperoleh akan lebih maksimal, begitu juga sebaliknya semakin rendah motivasi yang dimiliki siswa maka hasil yang diperoleh menjadi kurang maksimal.

\section{Pengaruh Ekonomi Keluarga dan Motivasi belajar terhadap Prestasi Belajar Siswa}

Hipotesis penelitian ketiga adalah terdapat pengaruh ekonomi keluarga dan motivasi belajar terhadap prestasi belajar siswa di SMK Teknomedika 2 Cibungbulang Bogor. Berikut rumusan hipotesisnya:

$\mathrm{H}_{0} \quad$ : Tidak terdapat pengaruh yang signifikan ekonomi keluarga dan motivasi belajar secara bersama-sama terhadap prestasi belajar siswa di SMK Teknomedika 2 Cibungbulang Bogor.

$\mathrm{H}_{1} \quad$ : Terdapat pengaruh yang signifikan ekonomi keluarga dan motivasi belajar secara bersama-sama terhadap prestasi belajar siswa di SMK Teknomedika 2 Cibungbulang Bogor.

Untuk menjawab hipotesis tersebut, dilakukan analisis regresi linear berganda dan uji F. Pedoman untuk uji F ini adalah sebagai berikut:

- Jika nilai sig < 0,05 atau $\mathrm{F}$ hitung $>\mathrm{F}$ tabel, maka terdapat pengaruh variabel $\mathrm{X}$ terhadap variabel Y 


\section{As-Syari: Jurnal Bimbingan É Konseling Keluarga}

- Jika nilai sig $>0,05$ atau $\mathrm{F}$ hitung $<\mathrm{F}$ tabel, maka tidak terdapat pengaruh variabel $\mathrm{X}$ terhadap variabel $\mathrm{Y}$

Hasil perhitungan analisis regresi linear berganda dan uji t pengaruh ekonomi keluarga dan motivasi belajar secara bersama-sama terhadap prestasi belajar siswa dengan menggunakan program SPSS versi 17 dapat dilihat pada tabel 4.16 di bawah ini:

Tabel 4.16 Hasil Analisis Regresi dan Uji t Ekonomi keluarga dan Motivasi belajar terhadap Prestasi Belajar Siswa

Coefficientsa

\begin{tabular}{|c|c|c|c|c|c|c|}
\hline \multirow{2}{*}{\multicolumn{2}{|c|}{ Model }} & \multicolumn{2}{|c|}{$\begin{array}{l}\text { Unstandardized } \\
\text { Coefficients }\end{array}$} & \multirow{2}{*}{\begin{tabular}{|l|} 
Standardized \\
Coefficients
\end{tabular}} & \multirow[t]{2}{*}{$t$} & \multirow[t]{2}{*}{ Sig. } \\
\hline & & B & Std. Error & & & \\
\hline \multirow[t]{3}{*}{1} & (Constant) & 34.766 & 5.881 & & 5.912 & 0.000 \\
\hline & $\begin{array}{l}\text { Ekonomi } \\
\text { Keluarga }\left(\mathrm{X}_{1}\right)\end{array}$ & 0.223 & 0.045 & 0.487 & 4.910 & 0.000 \\
\hline & $\begin{array}{l}\text { Motivasi belajar } \\
\left(\mathrm{X}_{2}\right)\end{array}$ & 0.332 & 0.067 & 0.490 & 4.944 & 0.000 \\
\hline
\end{tabular}

a. Dependent Variable: Prestasi Belajar Siswa

Berdasarkan hasil uji koefisien korelasi ekonomi keluarga dan motivasi belajar terhadap prestasi belajar siswa, maka diperoleh persamaan regresinya yaitu $\mathrm{Y}=34,766+$ $0,223 X_{1}+0,332 X_{2}$. Nilai persamaan $X_{1}$ dan $X_{2}$ adalah positif, artinya terdapat pengaruh ekonomi keluarga dan motivasi belajar terhadap prestasi belajar siswa di SMK Teknomedika 2 Cibungbulang Bogor. Dengan peningkatan variabel ekonomi keluarga sebesar 0,223, maka prestasi belajar siswa di SMK Teknomedika 2 Cibungbulang Bogor akan meningkat juga sebesar 0,223. Ini juga berlaku dengan peningkatan variabel motivasi belajar sebesar 0,332, maka prestasi belajar siswa di SMK Teknomedika 2 Cibungbulang Bogor akan meningkat juga sebesar 0,332.

Tabel 4.17 Uji Koefisien Regresi Ekonomi Keluarga dan Motivasi belajar terhadap Prestasi Belajar Siswa

ANOVA $^{b}$

\begin{tabular}{|l|lr|l|l|l|l|}
\hline Model & $\begin{array}{l}\text { Sum } \\
\text { Squares }\end{array}$ & Df & Mean Square & F & Sig. \\
\hline $1 \quad$ Regression & 382.348 & 2 & 191.174 & 44.880 & $0.000^{\text {a }}$ \\
& $\begin{array}{l}\text { Residual } \\
\text { Total }\end{array}$ & 166.128 & 39 & 4.260 & & \\
\hline
\end{tabular}

a. Predictors: (Constant), Ekonomi Keluarga, Motivasi Belajar

b. Dependent Variable: Prestasi Belajar Siswa 


\section{As-Syari: Jurnal Bimbingan E̊ Konseling Keluargan}

Dari uji Anova atau Uji F dengan menggunakan SPSS versi 17 diperoleh nilai Sig hitung $=0,000$ dan nilai $F_{\text {hitung }}=27,867$. Dengan menggunakan tingkat signifikansi $\alpha=5 \%$ atau 0,05, $\mathrm{df}_{1}=\mathrm{k}-1=3-1=2$ dan $\mathrm{df}_{2}=\mathrm{n}-\mathrm{k}=42-3=39$, maka diperoleh $\mathrm{F}_{\text {tabel }}$ sebesar 3,238 . Nilai $F_{\text {hitung }}$ lebih besar dari $F_{\text {tabel }}(44,880>3,238)$ dan nilai Sig hitung 0,000 lebih kecil dari 0,05. Dengan demikian hipotesis nol $\left(\mathrm{H}_{0}\right)$ ditolak dan hipotesis alternatif $\left(\mathrm{H}_{1}\right)$ diterima, yang berarti terdapat pengaruh yang signifikan antara ekonomi keluarga dan motivasi belajar secara bersama-sama terhadap prestasi belajar siswa di SMK Teknomedika 2 Cibungbulang Bogor.

Tabel 4.18 Koefisien Determinasi Ekonomi Keluarga dan Motivasi belajar terhadap Prestasi Belajar Siswa

\begin{tabular}{|l|l|l|l|l|}
\hline Model & $\mathrm{R}$ & R Square & $\begin{array}{l}\text { Adjusted } \\
\text { Square }\end{array}$ & $\begin{array}{l}R \\
\text { Std. Error of the } \\
\text { Estimate }\end{array}$ \\
\hline 1 & $0.835^{\mathrm{a}}$ & 0.697 & 0.682 & 2.064 \\
\hline
\end{tabular}

a. Predictors: (Constant), Ekonomi Keluarga, Motivasi Belajar

b. Dependent Variable: Prestasi Belajar Siswa

Dari uji determinasi, diperoleh nilai korelasi (R) sebesar 0,755. Hal ini menunjukkan adanya korelasi antara ekonomi keluarga dan motivasi belajar secara bersama-sama terhadap prestasi belajar siswa sebesar 0,755, dengan koefisien determinasi $\left(\mathrm{R}^{2}\right)$ sebesar 0,697 atau 69,7\%. Dengan demikian variabel ekonomi keluarga dan motivasi belajar memberikan pengaruh terhadap perubahan prestasi belajar siswa sebesar 69,7\%, sedangkan sisanya 30,3\% dipengaruhi oleh variabel-variabel lain yang tidak diteliti dalam penelitian ini.

Dari hasil analisis di atas, maka hipotesis penelitian ketiga diterima, yang artinya terdapat pengaruh yang signifikan ekonomi keluarga dan motivasi belajar secara bersama-sama terhadap prestasi belajar siswa di SMK Teknomedika 2 Cibungbulang Bogor. Hal ini memberikan makna bahwa baik tingkat ekonomi keluarga maupun motivasi belajar di SMK Teknomedika 2 Cibungbulang Bogor mampu meningkatkan prestasi belajar secara optimal.

Hasil penelitian ini mendukung teori yang sudah ada seperti yang dikemukakan Ahmadi dalam bukunya, bahwa faktor-faktor yang mempengaruhi prestasi belajar ada dua, yaitu faktor internal seperti intelegensi, bakat, minat, sikap dan motivasi, dan faktor eksternal seperti lingkungan sekolah, lingkungan keluarga (yang meliputi : cara mendidik anak, suasana keluarga, pengertian keluarga, keadaan sosial ekonomi, latar belakang kebudayaan dan lain-lain) dan lingkungan masyarakat. ${ }^{1}$

Berdasarkan pendapat Ahmadi tersebut, dapat dijelaskan bahwa ekonomi keluarga dan motivasi belajar dapat mempengaruhi prestasi belajar siswa. Semakin tinggi tingkat ekonomi keluarga dan motivasi belajar, maka prestasi belajar siswa juga akan meningkat, begitupun sebaliknya jika ekonomi keluarga dan motivasi belajar siswa rendah, maka prestasi belajar siswa pun akan menurun.

\footnotetext{
${ }^{1}$ Ahmadi. Sosiologi Pendidikan, Jakarta: PT Rineka Cipta, h. 78.
} 


\section{As-Syari: Jurnal Bimbingan है Konseling Keluarga}

Kondisi ekonomi keluarga dan motivasi belajar merupakan faktor penting dalam pencapaian prestasi belajar siswa. Kondisi ekomoni keluarga yang baik serta didukung dengan motivasi belajar siswa yang tinggi akan meningkatkan prestasi belajar siswa.

\section{E. KESIMPULAN DAN REKOMENDASI}

\section{Kesimpulan}

Berdasarkan hasil penelitian dan pembahasan tentang "Pengaruh Kondisi Ekonomi Keluarga dan Motivasi Belajar Terhadap Prestasi Belajar Siswa Pada Mata Pelajaran Kewirausahaan Kelas XII di SMK Teknomedika 2 Cibungbulang Bogor", dapat disimpulkan bahwa:

1. Terdapat pengaruh yang signifikan ekonomi keluarga terhadap prestasi belajar siswa di SMK Teknomedika 2 Cibungbulang Bogor sebesar 50,7\%.

2. Terdapat pengaruh yang signifikan motivasi belajar terhadap prestasi belajar siswa di SMK Teknomedika 2 Cibungbulang Bogor sebesar 51,0\%.

3. Terdapat pengaruh yang signifikan antara ekonomi keluarga dan motivasi belajar secara bersama-sama terhadap prestasi belajar siswa di SMK Teknomedika 2 Cibungbulang Bogor sebesar 69,7\% sedangkan sisanya 30,3\% dipengaruhi oleh variabel-variabel lain yang tidak diteliti dalam penelitian ini.

\section{Rekomendasi}

Berkaitan dengan simpulan di atas, maka dapat diajukan rekomendasi sebagai berikut:

\section{Kepala Sekolah}

Dari hasil penelitian tersebut, sekolah dapat menciptakan lingkungan belajar dengan memberikan pelatihan-pelatihan selain materi dan praktek di sekolah kepada siswa untuk mata pelajaran yang membutuhkan keterampilan seperti kewirausahaan. Sehingga untuk siswa yang akan lulus sudah mampu mempersiapkan diri akan bekerja di dunia usaha/industri atau menjadi entrepreneur.

\section{Bagi Guru}

Guru mampu meningkatkan sistem kegiatan belajar mengajar dan motivasi belajar pada siswa khusus untuk mata pelajaran kewirausahaan dengan mengembangkan pengajaran teori dan praktek dengan cara memberi latihan dan tugas yang berhubungan dengan materi kewirausahaan, sehingga prestasi belajar siswa meningkat.

\section{Bagi Orang Tua}

Orang tua sebagai pendidik pertama bagi anaknya harus meningkatkan kondisi ekonomi keluarga dalam hal ini tingkat pendapatannya agar mampu membiayai dan memfasilitasi kebutuhan belajar anak serta selalu memotivasi anak agar lebih giat belajar sehingga dapat meningkatkan hasil belajarnya.

\section{Bagi Siswa}

Siswa yang mau meningkatkan prestasi belajarnya harus memperhatikan faktorfaktor yang mempengaruhi belajar itu sendiri dengan cara memotivasi diri sendiri, memiliki harapan dan cita-cita di masa depan, kegiatan belajar yang menarik dan menjaga lingkungan tetap kondusif.

\section{Bagi Peneliti Lain}




\section{As-Syari: Jurnal Binbingan है Konseling Keluarga}

Bagi peneliti lain, hendaknya mengembangkan faktor-faktor lain yang berpengaruh pada prestasi belajar mata pelajaran kewirausahaan.

\section{DAFTAR PUSTAKA}

Ahmadi, Abu. (1991). Psikologi Sosial, Jakarta: Rineka Cipta. Ahmadi. (2004). Sosiologi Pendidikan, Jakarta: PT Rineka Cipta. Alwi, Hasan, (2007). Kamus Besar Bahasa Indonesia, Jakarta : Balai Pustaka. Arikunto, Suharsimi. (2002). Prosedur Penelitian Suatu Pendekatan Praktek, Jakarta: PT. Rineka Cipta.

BKKBN. (2004). Kurikulum dan Modul 8 Fungsi Keluarga, Jakarta : BKKBN.

Dahlan, Sitti Salmiah. (2011). Manajemen Pendidikan Islam, Jakarta: Rabbani Press. Dalyono, M. (2009). Psikologi Pendidikan, Jakarta: Rineka Cipta. Depdiknas. (2003). Undang-Undang RI No. 20 Tahun 2003 Tentang Sistem Pendidikan Nasional, Jakarta : Fokus Media.

Hamalik, Oemar. (2003). Prosedur Belajar Mengajar, Jakarta: Bumi Aksara. Nasution, (2004). Sosiologi Pendidikan, Bandung : Jemmars. Ormrod, Jeanne Ellis. (2008). Psikologi Pendidikan: Membantu Siswa Tumbuh dan Berkembang, Jakarta: Erlangga, Ed.6, Jilid 2.

Prawira, PA. (2013). Psikologi Pendidikan Dalam Perspektif Baru, Yogyakarta: Ar-Ruzz Media.

Sa'ud, Udin Syaefuddin., Makrum, Abin Syamsuddin. (2005). Dasar-dasar Perencanaan pendidikan, Bandung: Remaja Rosda Karya.

Suryani, T. (2008). Perilaku Konsumen, Yogyakarta: Graha Ilmu. Syah, M. (2012). Psikologi Pendidikan, Jakarta: Rajawali Press.

Siregar, Eveline., Nara, Hartini. (2010). Teori dan Pembelajaran, Bogor : Ghalia Indonesia. Soejanto. (2002). Guru dan Siswa, Jakarta: Tut Wuri.

Statistikskripsitesis.blogspot.com/2014/12.pengertian-tentang-software-spss.html diakses 22 januari 2020

Tu'u, T. (2004). Peran Disiplin Pada Perilaku dan Prestasi Siswa. Jakarta: PT. Gramedia Widiasarana.

Uno, Hamzah B. (2011). Teori Motivasi dan Pengukurannya : Analisis di bidang Pendidikan, Jakarta: Bumi Aksara.

Yamin, Martinis. (2006). Sertifikasi Profesi Keguruan di Indonesia, Jakarta: Gaung Persada Press, Cet.2. 


\section{As-Syari: Jurnal Binbingan है Konseling Keluargena}

\section{Profil Penulis}

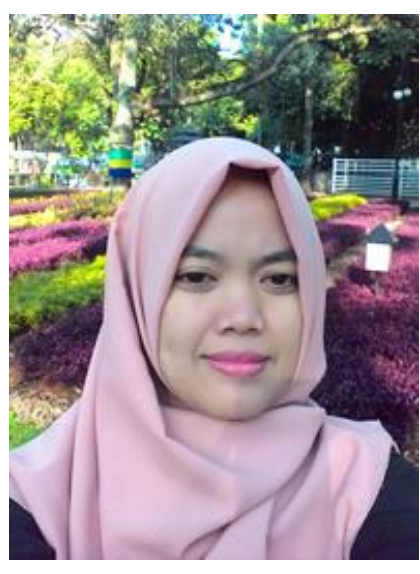

Yati Nurhidayati, lahir di Bogor tanggal 19 Februari 1981 Ayah bernama Mad Suroh (Alm) dan Ibu bernama Jumiati. Pendidikan formal ditempuh pada (1987-1993) di MI Muhammadiyah Leuwiliang Bogor, (1993-1996) di SLTPN 1 Leuwiliang Bogor, (1996-1999) di SMUN 1 Leuwiliang Bogor, (2008-2011) S1 STAIT Modern Sahid Bogor Jurusan Ekonomi Syariah Program Studi Perbankan Syariah, (2017-2019) Pascasarjana (S2) IAIN Laa Roiba Bogor Program Studi Pendidikan Agama Islam, Konsentrasi Manajemen Pendidikan Islam.

Pengalaman Kerja : (2001-2010) di Lembaga Keuangan Syariah KBMT Khairu Ummah Leuwiliang Bogor, (April 2011- Desember 2011) HCPDM Project MDMC Pimpinan Pusat Muhammadiyah Jakarta. (2012-2016) Kepala Bagian Administtasi Umum dan Keuangan Institut Agama Islam Sahid (INAIS) Bogor. (2016-2018) Guru tidak tetap pada Jurusan Bisnis Manajemen di SMK Teknomedika 2 Cibungbulang Bogor. (2016-2018) Bagian Administrasi Akademik (BAAK) Institut Agama Islam Nasional (IAI-N) Laa Roiba Bogor. (2018-2019) Kepala Bagian Administtasi Umum dan Keuangan (BAUK) STKIP Muhammadiyah Bogor.

Pengalaman Organisasi Periode : (2015-2020) Pimpinan Daerah Aisyiyah (PDA) Kab. Bogor jabatan sebagai Sekretaris Majelis Ekonomi, Anggota Lembaga Lingkungan Hidup dan Penanggulangan Bencana. (2016-2020) Pimpinan Daerah Nasyiatul Aisyiyah (PDNA) Kab. Bogor jabatan sebagai Bendahara Umum. (2013-2016) Pimpinan Daerah Nasyiatul Aisyiyah (PDNA) Kab. Bogor jabatan sebagai Ketua Departemen Kaderisasi. (2012-2016) Pimpinan Cabang Nasyiatul Aisyiyah (PCNA) Leuwiliang jabatan sebagai Wakil Bendahara.

Motto hidup : Ambillah teladan dari Siti Asiah kesabarannya, Siti Khadijah kesetiaannya, Siti 'Aisyah kejujurannya dan Siti Fatimah keteguhannya. 